\title{
THE USE OF MINIMAL PAIR TECHNIQUE IN TEACHING PRONUNCIATION AT THE SECOND YEAR STUDENTS OF SMAN 4 BANTIMURUNG
}

\author{
Isna Nur \\ Universitas Islam Negeri Alauddin \\ Isnanur7177@yahoo.com \\ Indah Fadhilah Rahman \\ Universitas Islam Negeri Alauddin \\ Indab.fadbilab@uin-alauddin.ac.id
}

\begin{abstract}
This objectives of this research were to find out (1) Use of minimal pair technique in teaching pronunciation at the second year students of SMAN 4 Bantimurung. (2) Whether the minimal pair technique effective in teaching pronunciation or not at the second year students of SMAN 4 Bantimurung. This researcher applied quasi-experimental design with non-equivalent control group design. The sample was taken by using purposive sampling that devided into two groups were $\mathbf{2 5}$ students as experimental class and $\mathbf{2 5}$ students as control class. The result of the data indicated that there was a significance difference between students' post-test in the experimental class and the control class. The mean score of post-test (2.96) in the experimental class was greater than the mean score of post-test (2.2) in the control class and the standard deviation of the post-test $(\mathbf{0 . 8 3})$ in experimental class was greater than the standard deviation of the post-test (0.4) in control class and the value of t-test (5.84) was higher than $\mathrm{t}$-Table (2.021). Based on the result of this study implies that use of minimal pair technique was effective to improve the students' pronunciation ability at the second year students of SMA Negeri 4 Bantimurung. Besides, the significant improvement can be seen from the students' response to researcher's performance. They seem more active during teaching learning activity. Therefore, the researchers suggests that the English teacher should implement minimal pair technique in teaching pronunciation in order to improve students' pronunciation ability.
\end{abstract}

Keywords: Pronunciation, Minimal Pair Technique

\section{A. INTRODUCTION}

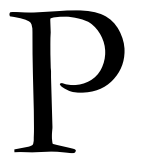

ronunciation is one of the language components in English which is needed to be learned to support the development of language skills mastery of the students specially in speaking, and it hold an important role in English teaching since mostof country has totally different pronunciation counted Indonesia.

There are excessive differences between English and Indonesian Language especially in its of symbols and sounds. For instance, English language has vowel and consonant sounds changing after becoming word. Whereas, Indonesian pronunciation has no various sound after becoming word. For instance, if the consonant /s/ sound is combined with /k/ /i/ and /d/ sounds in "kids" / kidz/, the /s/ sounds becomes / $\mathrm{z} /$ or voiced sound. While Indonesian for instance if the letter $\mathrm{M} / \mathrm{m} /$ combined with sound /a/ and / s/ sounds in word is "Mas" /mas/ 
there is no vowel sound changing at all. Ramelan (2005:5) said the greater similarity between them; the less difficult it will be for various sounds after becoming a word.

Teaching pronunciation in the classroom involved many challenges, for instance, about the time. English is learning at the second year students of Senior High School only two hours in a week. This statement means that in teaching-learning English process in Indonesia still has limited time, so there is no adequatetime to provide proper attention in pronunciation. Another problem is, the students' mother tongue which is influencing them in pronouncing the English words, the students' problems is appeared when they try to transferring their first language into their target language (English). Furthermore, the other problem faced by students is the difficulties of students in differentiating the pronunciation of the words that have similar sound. They also pronounce the English word as written. For example in English "Umbrella" pronounced / $\Lambda \mathrm{m}$ 'brelə/, but isna pronounce it /Umrella/ the same as written word.

According to Harmer (2007:59) for all those peoples who learn English, being made aware of pronunciation issues will give them benefit not only to their own production but also to their own understanding of spoken English. This means, the students who have good pronunciation, they can speak and understand the spoken English and being understood by the others. Therefore it is prominent for the students to learn pronunciation.

Based on to the researcher's observation which was done on $9^{\text {th }}$ November 2016 at the second grade of SMAN 4 Bantimurung in class XI IPS 1 and unstructured interview with the English teacher of this classroom, the researchers found some problems that were appeared concerning students' ability in pronunciation. The common problem that the researchers found in this class is the students have difficulty in differentiating the pronunciation of words that have similar sound. For instance, the students' difficulties in differentiating and pronouncing vowel sounds in words least / li:st/ and list / list/. In addition students also have difficulty in differentiating and pronouncing consonant sounds for example the words live / live / and life / lifel.

A numbers of students' problems above are very prominent to solve. Therefore, referring to the way to solve the students' problems above; the researcher used an interesting technique which was called minimal pairs. So far it is considered to be a good way of learning English pronunciation.

Fromkim, Rodman, \& Hayms (2003:277) stated that minimal pair is two words which different meanings that are identical except for one sound segment that occurs in the same place in the string. Crystal (2008) point out that aminimal pair carries two words which are similar to each other except for only one sound which can be vowel as well as a consonant (for example, 
cat and bat, it and fat and so on). It is also supported by Tuan (2010), he explains that minimal pairs are pairs of words that differ in meaning on the basis of a change in only one sound. Based on the three explanations above the researchers can conclude that minimal pair is a pair of words which differ by only one sound. Teaching pronunciation by using this technique, supposed be able to help students to establish the habit of thinking in English. To distinguish the English sounds that has the similar sound obscurely by pairing those two words, so it could be easy to recognize whether the sounds pronounced contextually or not, because wrong pronunciation could be misunderstanding and obstruct the communication fluency. Technique of minimal pair is interesting activity because it is considered easy to understand and effective. Besides, the students would know many English words. So the students not only had good pronunciation but also enriched their vocabulary.

Based on the problem stated previously, the researchers conduct a research entitled "The use of minimal pair technique in teaching pronunciation at the second year of SMAN 4 Bantimurung". The technique of minimal pair hopefully helps the students to distinguish the similar sound in English word theoretically and contextually and to practice their fluency and accuracy in pronouncing words.

\section{B. LITERATURE REVIEW}

Some researchers have conducted reseraches related to "the minimal pair technique" and what they have found are shown, such as Tuan (2010) conducted a study about teaching English discrete sound trough minimal pair. He wanted to know how far the minimal pairs is facilitated non-majored students at Hung Vuong University in recognizing and producing English discrete sound as well as in what way and to what extend do minimal pairs facilitate the teaching and learning of English discrete sound. The result of his research was both teachers and students are used minimal pairs as tool of teaching and learning. The students' recognition and production in English discrete sound also showing an improvement.

Fatmawati (2014) pointed in her research the application of minimal pair to improve the pronunciation of voiced and voiceless sound (a true-experiment research at the eighth grade students of SMPN 13 Palu in academic year 2013/2014) stated that the application of minimal pairs effective to improve the pronunciation of voiced and voiceless sounds. It means that the technique made contribution in teaching pronounciation.

Nuraeni (2015) who did a reserach about the effectiveness of minimal pairs toward students' English pronunciation (a pre-experimental research at the seventh grade of smp Muhammadiyah 17 Ciputat in academic year 2014/2015) conclude that teaching by minimal pair technique is effective and helping the students' ability and achievements in pronunciation. 
The results of her research showed that there was improvement of students' pronunciation after being taught using minimal pairs.

Putri (2015) who did a research about the effectiveness of minimal pairs drills toward students' ability in pronouncing similar sounds of words (a quasi-experiment study in the eight grade Mts. Khazanah Kebajikan in academic year 2014/2015) concludes that there is significance effect of minimal pairs drill technique on students' ability in pronouncing similar sound of words. It was proven by the data shown. The value of $\mathrm{c}_{\text {ount }}$ was 2.25 while the value of $t_{\text {table }}$ in the significance level $5 \%$ was 2.02 . Therefore the score of $c_{\text {ounts }}$ higher than $t_{\text {table }} \mathrm{Or}$ 2.25>2.02. It means that the alternative hypothesis $\left(\mathrm{H}_{\mathrm{a}}\right)$ is accepted and the null hypothesis is rejected $\left(\mathrm{H}_{0}\right)$.

Mahmood, et al (2015) conducted a research about the effectiveness of minimal pairs in teaching phonemic transcription. In his research the researcher wanted to know the effectiveness of minimal pairs in developing students' recognition of English phonemes. The result of this research showed that the experimental group performed far better that the control group due to the treatment, it is mean that minimal pairs is effective in developing students' recognition of English phonemes.

Sari (2011) in her thesis entitled improving students' pronunciation by using minimal pair drill (a classroom action research at grade VII.3 SMPN.66 Jakarta) concluded that the implementation of minimal pair in improving students' pronunciation is effective in using since the criteria of success were achieved. The criterion of success that has been agreed by the teacher and researcher is if the improvement from pre-test to post-test is 30\% and the result was $34.01 \%$, the improvement of students' mean score from pre-test result to post-test.

Based on some reviews of related research above, the different between our research were: in Tuan (2010), he used minimal pair in teaching English discrete sound, in Fatmawati, she used the application of minimal pair to improve the pronunciation of voiced and voiceless sound. In Nuraeni, she used minimal pair technique to improve students' ability in differentiating long and short vowel. In Putri, she used minimal pair drills towards students' ability in differentiating the pronunciation of similar sound. While in Mahmood, he used minimal pair in teaching phonetic transcription to know the effectiveness in developing students' recognition of English Phonem. While in our research, the reserchers used minimal pair technique to teach pronunciation focused on consonant sound. 


\section{RESEARCH METHOD}

In this research, the researchers asserted quasi-experimental research design. According to Nunan (1991:105) that quasi experimental research is defined as experimental design which is conducted as if it look like the real.

The form of Quasi-Experimental design used in this research was Non-equivalent Control Group Design with experimental and control class to find out the enhancement of students' ability in differentiating the pronounciation of the same sound of words by using minimal pair technique.

In the experimental class, the researchers applied minimal pair technique in teaching pronunciation while in control class used conventional technique. The researchers used pre-test and post-test design in both experimental and control class. The aim was to prove or disprove a hypothesis mathematically, with statistical analysis.

This was the model of Quasi Experimental Design, exactly Pre-test-Post-test Control Group Design.

\section{Table 1. Research Design}

\begin{tabular}{|c|c|c|c|}
\hline $\mathrm{E}$ & $\mathrm{O}_{1}$ & $\mathrm{X}$ & $\mathrm{O}_{2}$ \\
\hline $\mathrm{C}$ & $\mathrm{O}_{3}$ & & $\mathrm{O}_{4}$ \\
\hline
\end{tabular}

Where:

E : Experimental class

C : Control class

$\mathrm{O}_{1}$ : Pre-test (in experimental class)

$\mathrm{O}_{3}$ : Pre-test (in control class)

$\mathrm{X}$ : Treatment that will be given for experimental class

$\mathrm{O}_{2}$ : Post-test (in experimental class)

$\mathrm{O}_{4}$ : Post-test (in control class)

(Sugiyono, 2010:116)

\section{FINDING AND DISCUSSION}

\section{Findings}

a. The classification of students' pre-test and post-test score in experimental class

The following tables showed the classification of frequency and percentage the score of students' pronunciation at the second year students of SMAN 4 Bantimurung in pre-test and post-test of experimental class. 
Table 4.1.The rate percentage of score experimental class in pre-test

\begin{tabular}{|c|l|c|c|c|}
\hline No & \multicolumn{1}{|c|}{ Classification } & Score & Frequency & Percentage \\
\hline 1 & Very Good & $4.01-5.00$ & 0 & $0 \%$ \\
\hline 2 & Good & $3.01-4.00$ & 0 & $0 \%$ \\
\hline 3 & Average & $2.01-3.00$ & 4 & $16 \%$ \\
\hline 4 & Poor & $1.01-2.00$ & 11 & $44 \%$ \\
\hline 5 & Very Poor Total & $0.01-1.00$ & 10 & $40 \%$ \\
\hline \multicolumn{2}{|c|}{} & 25 & $100 \%$ \\
\hline
\end{tabular}

The table above showed the rate percentage and frequency of score experimental class in pre-test. It showed that none of the students $(0 \%)$ can be classified very good and good in pronouncing the minimal pair, 4 students $(16 \%)$ as an average score, 11 students (44\%) as a poor score in and 10 students $(40 \%)$ classified as a very poor score.

Table 3. The rate percentage of score experimental class in post-test

\begin{tabular}{|c|l|c|c|c|}
\hline No & Classification & Score & Frequency & Percentage \\
\hline 1 & Very Good & $4.01-5.00$ & 1 & $4 \%$ \\
\hline 2 & Good & $3.01-4.00$ & 5 & $20 \%$ \\
\hline 3 & Average & $2.01-3.00$ & 11 & $44 \%$ \\
\hline 4 & Poor & $1.01-2.00$ & 8 & $32 \%$ \\
\hline 5 & Very Poor & $0.01-1.00$ & 0 & $0 \%$ \\
\hline \multicolumn{2}{|c|}{ Total } & 25 & $100 \%$ \\
\hline
\end{tabular}

The table 4.2 above showed that in post-test, there were 1 student (4\%) got very good score, 5 students (20\%) got good score, 11 students (44\%) got average score, 8 students (4\%) got poor score and none of the students got very poor score.

Based on the result above, it can be concluded that the percentage in post-test was higher than the percentage in pre-test.

\section{b. The classification of students' pre-test and post-test score in control class}

The following tables showed the classification of frequency and percentage the score of students' pronunciation at the second year students of SMAN 4 Bantimurung in pre-test and post-test of control class.

Table 4. The rate percentage of score control class in pre-test

\begin{tabular}{|c|l|c|c|c|}
\hline No & Classification & Score & Frequency & Percentage \\
\hline 1 & Very Good & $4.01-5.00$ & 0 & $0 \%$ \\
\hline 2 & Good & $3.01-4.00$ & 0 & $0 \%$ \\
\hline
\end{tabular}




\begin{tabular}{|c|l|c|c|c|}
\hline 3 & Average & $2.01-3.00$ & 3 & $12 \%$ \\
\hline 4 & Poor & $1.01-2.00$ & 12 & $48 \%$ \\
\hline 5 & Very Poor Total & $0.01-1.00$ & 10 & $40 \%$ \\
\hline \multicolumn{2}{|c|}{} & 25 & $100 \%$ \\
\hline
\end{tabular}

The table above shows the rate percentage and frequency of the students' control class in pre-test. It shows that none of the students got very good and good score, 3 students $(12 \%)$ got average score, 12 students (48\%) got poor score, and 10 students (40\%) got very poor in pronouncing minimal pair.

Table 5. The rate percentage of score control class in post-test

\begin{tabular}{|c|l|c|c|c|}
\hline No & Classification & Score & Frequency & Percentage \\
\hline 1 & Very Good & $4.01-5.00$ & 0 & $0 \%$ \\
\hline 2 & Good & $3.01-4.00$ & 2 & $8 \%$ \\
\hline 3 & Average & $2.01-3.00$ & 2 & $8 \%$ \\
\hline 4 & Poor & $1.01-2.00$ & 18 & $72 \%$ \\
\hline 5 & Very Poor & $0.01-1.00$ & 3 & $12 \%$ \\
\hline \multicolumn{2}{r|r|}{ Total } & 25 & $100 \%$ \\
\hline
\end{tabular}

The table above shows that in post-test, there were none student $(0 \%)$ got very good score, 2 students (8\%) got good score, 2 students (8\%) got average score, 18 students $(72 \%)$ got poor score, and 3 students (28\%) got very poor score.

Viewed from the result above, it can be concluded that the percentage in post-test was different in the rate percentage in pre-test.

\section{c. The mean score and standard deviation of experimental class and control class}

After calculating the result of the students' score, the mean scores and the standards deviation for both classes can be presented by the following table.

Table 6. The mean score and standard deviation of experimental and control class in pre-test

\begin{tabular}{|c|c|c|}
\hline Class & Mean Score & Standard Deviation \\
\hline Experimental & 1.76 & 0.72 \\
\hline Control & 1.72 & 0.62 \\
\hline
\end{tabular}

The table above shows that, the mean score in pre-test of experimental class was (1.76) and the standard deviation was (0.72), while the mean score of students in control class was (1.72) where the standard deviation was (0.62). It means that, the students' ability in pre-test were still in the same level. 
Table 7. The mean score and standard deviation of experimental and control class in post-test.

\begin{tabular}{|c|c|c|}
\hline Class & Mean Score & Standard Deviation \\
\hline Experimental & 2.96 & 0.83 \\
\hline Control & 2.2 & 0.4 \\
\hline
\end{tabular}

The table above shows that, the mean score of experimental class in post-test was (2.29) and the standard deviation of experimental class was (0.83), while the mean score of control class in post-test was (2.2) and its standard deviation was (0.4). It means that, the mean score of control class was lower than the mean score of experimental class.

\section{d. Hypothesis testing and the difference significant between the experimental and control class.}

The significant score between experimental and control class can be calculated by using tTest. The result of $\mathrm{t}$-Test can be seen in the table 8 as follows:

Table 8. The significance score of experimental and control class

\begin{tabular}{|c|c|c|}
\hline Variable & t-Test & t-Table \\
\hline Post-Test & 5.84 & 2.021 \\
\hline
\end{tabular}

The table above shows the result of test of significance testing. For the level of significance (P) 0.05 and the degree of freedom $(\mathrm{df})(\mathrm{N} 1+\mathrm{N} 2)-2=(25+25)-2=48$, showed that the value of the t-Test was higher than $\mathrm{t}$-Table. The result of the test clearly showed that there was significance different between the students' score in the experimental and control class after applying the treatment of minimal pair technique. It indicates that the minimal pair technique is very effective in teaching pronunciation. It means $\mathrm{H}_{0}$ is rejected and $\mathrm{H}_{1}$ is accepted because the T-test is higher than t-Table $(\mathbf{5 . 8 4}>\mathbf{2 . 0 2 1})$. Hence, the hypothesis of the researcher are accepted.

\section{E. DISCUSSION}

Teaching English Pronunciation using minimal pair technique is suitable to be applied in the classroom. This technique helped the students to increase their ability in English pronunciation. Teaching English pronunciation by using minimal pair technique indicate the students can easily to differentiate the similar sound of words. The result of this research shows that the students' scores in pronunciation test particularly in similar sound of consonant words were improved after the treatment in experimental class using minimal pair technique. Most of 
them got average score, some got good score and there was one got very good score in posttest.

Based on the finding above that there were some advantages of minimal pair technique in teaching pronunciation, which were: 1) the teaching material can be given gradually and regularly, 2) minimal pair technique effective in facilitating pronounciation, 3) minimal pair can helps students to practice listening which is also can enrich students' vocabulary. Besides, minimal pair technique also has disadvantage for example; the students likely not hear the differences between the words so they did pronounce the words incorrectly.

The gap analysis of the mean score in the post-test between the experimental and control class ensured if the technique was effective. The mean score of the students in experimental class was 2.96 and 2.2 for controlled class. It means the gap of the students' score of the experimental and control class was 0.76 . The explanation of the gap between the two classes indicates that the experimental class showed higher score than the control class.

The alternative hypothesis of this research would be accepted if the t-test is higher than $\mathrm{t}$ table value. The result of the hypothesis test showed that $t$-Test (5.9) was higher than $t$-Table (2.021). Therefore, null hypothesis $\left(\mathrm{H}_{0}\right)$ was rejected and the alternative hypothesis $\left(\mathrm{H}_{1}\right)$ was accepted.

According to those statements above, the researchers concluded that minimal pair technique was giving significance effect towards students' ability in pronouncing similar sound of consonant words.

\section{F. CONCLUSION}

After analyzing the data, the researchers make conclusions as follows:

The researchers concluded that the application or the use of minimal pair technique was effective in teaching pronunciation at the second year students of SMAN 4 Bantimurung. It can be seen by the result of the data analysis. There was significant different between the result of the score in pre-test and post-test. The students' score in pronunciation test before applying minimal pair technique in teaching pronunciation were still low. It was different from the students' ability after applying minimal pair technique in teaching pronunciation. It can be found in the mean score of the students' in pre-test and post-test. In the pre-test the score was $\mathbf{1 . 7 6}$ while the result of post-test increased to 2.96. Obviously, it defined that the pronunciation of the second grade students at SMAN 4 Bantimurung was improved afterthe treatment. It is mean that Minimal Pair Technique was effective to used in teaching pronunciation particularly to consonant words that have similar in sound. 


\section{G. SUGGESTIONS}

Based on the conclusions above, the researchers would like to deliver some suggestions to the following:

1. The teachers.

The first, pronunciation tends to be the component of language skill in teaching and learning English, it is very crucial to give more attention on it by providing enough time to focus on improving students' pronunciation. The second, the teacher should creatively find some novel methods which can motivate students in learning English and the teacher also should provide the students with more media that can support the material given, such as recording of native speaker, dictionary, and pictures and so on. The third, the researcher also suggests using Minimal Pair Technique as a method in teaching pronunciation and improving the material of minimal pair not only from text book but also from other sources.

2. The students

The researchers suggest to the students to keep practice the minimal pair to improve their pronunciation of similar sound and to be good learner who respect their teacher by pay attention to the lesson for supporting the learning process run well.

3. The another researchers.

The next researcher who want to use minimal pair technique in conducting their research, they should provide many more pairs of words that consisted of sounds will be tested before doing the treatment.

\section{BIBLIOGRAPHY}

Arikunto, S.(2006). Prosedur Penilaian Suatu Pendekatan Praktis. Jakarta: PT. Rineka Cipta.

Avery, Peter and Susan Ehrlich. (2009). Teaching American English Pronunciation. $2^{\text {nd }}$ Edition. Oxford: Oxford Edition Press.

Barlow. Jessica A. and Judith A. Geirut. (2002). Minimal Pair Approaches to Phonological Remediation. Seminar in Speech Language. Retereive from: www.researchgate.net/. On September $15^{\text {th }} 2017$.

Basri, H. (2006). A Course Book for English Phonology1. Palu: Taduloka University.

Bluman, Allan G. (2004) Elementary Statistic: A Step by Step Approach. New York: the McGraw-Hill Companies, Inc.

Byrne, Donn. (1987). Teaching Oral English. Long Man Publishing Group.

Dalton, E \&Seidlhofer, B. (2007). Pronunciation. Oxford: Oxford University Press. 
Fatmawati, T. (2014). The Application of Minimal Pair to Improve the Pronunciation of Voiced And Voiceless Sounds. Palu.

Fromkin, V., Rodman, R., \& Hymas, N. (2003). An Introduction to Language: Seventh Edition.

Gay, L.R. (2006). Education Research: Competencies for Analysis and Application. $8^{\text {th }}$ ed.United State: Earson Merrill Prenfile Hall.

Heaton, J. B. (1975). Writing English Language Text. New York: Longman Group UK Limited.

Hermer, Jeremy. (2007). The Practice of English Language Teaching. $4^{\text {th }}$ ed. New York: Longman.

Hornby, S.A. (1955). Oxford Advanced Learners' Dictionary. Oxford: Oxford University Press, 1995.

Jones, Daniel. (1986). The Pronunciation of English. Cambridge: Cambridge University Press.

Kelly, Gerald. (2000). How to Teach Pronunciation. England: Person Education Limited.

Kenwothy, J. (1987). Teaching English Pronunciation. London: Bluestone Press.

Lenneberg, E. H.(1967). The Geological Foundations of Language. New York: John Wiley and Sons.

Mahmood, A.(2015). Effectiveness of Minimal Pairs in Teaching Phoneme Transcription. Pakistan.

Marriane Celce-Murcia, Donna M. Brinton. and Janet M. Godwin. (1996). Teaching Pronunciation: A Refference for Teachers of English to Speaker of Other Language. New York: Cambridge University Press.

Nuraeni. N. (2015) The Effectiveness of Minimal Pairs towards Students' English Pronunciation. Ciputat: Skirpsi on Syarif Hidayatullah.

Otlowsi, M. Pronunciation. (2017). What are the Expectation. Journal: The Internet TESL Retrieved from http://www.iteslj.org./Article/Otlowsski Pronunciation. Htmlon September $26^{\text {th }}$.

Putri, Fara Zikara. (2015). The Effectiveness of Minimal Pair Drills toward Students' Ability in Pronouncing Similar Sound of Words. Jakarta; Skripsi on Syarif Hidayatullah.

Puwanto, N. (1992). Prinsip-Prinsip dan Teknik Evaluasi Pengajaran. Bandung: PT. Remaja Pesdakarya.

Ramelan. (1985). English Phonetics. Semarang: Ikip Semarang Press.

Sari, Y. (2011). Improving Students Pronunciation by Using Minimal Pair Drills. Skripsi: Syarif Hidayatullah State Islamic University; Jakarta. 
Volume 4, Number 2, December 2018

Sugiyono. (2015). Metode Penelitian Pendidikan: Pendekatan Kuantitatif, Kualitatif, dan R\&D. Edition XXII; Bandung: Alfabeta.

Sutomo. (1985). Teknik Penilaian Pendidikan. Surabaya: Bina Ilmu.

Tithraj, Acharya. (2010). Teaching Pronunciation in Kamal Raj Dahal (ed), circle of English Teacher (cet): Journal: Autum issue Vol. II, P 86. Nepal..

Tuan. Luu Trong. (2010). Teaching English Discreet Sound Trough Minimal Pair. Journal of Language Teaching and Research.

Ur, Penny. (1996). A course in Language Teaching: Practice and Theory. Cambridge: Cambridge University Press.

Yates, Linda. (2002). Fact Sheet-What Pronunciation Is?. Sydne: Amep Research Centre. 